\title{
A randomized double-blind clinical trial of posterior composite restorations with or without bevel: 1-year follow-up
}

\author{
Fábio Herrmann COELHO-DE-SOUZA', Junara Cristina CAMARGO², Tiago BESKOW², Matheus Dalmolin BALESTRIN², \\ Celso Afonso KLEIN-JÚNIOR ${ }^{3}$, Flávio Fernando DEMARCO ${ }^{4}$
}

\author{
1- DDS, MSD, PhD, Department of Conservative Dentistry, Federal University of Rio Grande do Sul, Porto Alegre, RS, Brazil. \\ 2- DDS, private practice, Cachoeira do Sul, RS, Brazil. \\ 3- DDS, MSD, PhD, Department of Dentistry, Lutheran University of Brazil, Cachoeira do Sul, RS, Brazil. \\ 4- DDS, PhD, Department of Operative Dentistry, Federal University of Pelotas, Pelotas, RS, Brazil.
}

Corresponding address: Prof. Dr. Flávio F. Demarco - Rua Gonçalves Chaves, 457 - Pelotas - RS - 96015-560 - Brasil - Phone: 55-5332256741 - R. 136 - e-mail: ffdemarco@gmail.com

Received: June 2, 2010 - Accepted: August 26, 2010

\section{ABSTRACT}

\begin{abstract}
O bjective: This randomized double-blind clinical trial compared the performance of posterior composite restorations with or without bevel, after 1-year follow-up. Material and Methods: Thirteen volunteers requiring at least two posterior composite restorations were selected. Twenty-nine cavities were performed, comprising 14 without bevel (butt joint) and 15 with bevel preparation of the enamel cavosurface angle. All cavities were restored with simplified adhesive system (Adper Single Bond) and composite resin (Filtek P60). A halogen light curing unit was used through the study. Restorations were polished immediately. Analysis was carried out at baseline, after 6 months and after 1 year by a calibrated evaluator (Kappa), according to the FDI criteria. Data were statistically analyzed by Mann-Whitney test $(p<0.05)$. Results: Beveled and non-beveled cavities performed similarly after 1 year follow-up, regarding to fractures and retention, marginal adaptation, postoperative hypersensitivity, recurrence of caries, surface luster and anatomic form. However, for surface and marginal staining, beveled cavities showed significantly better performance $(p<0.05)$ than butt joint restorations. Conclusions: It was concluded that the restorations were acceptable after 1 year, but restorations placed in cavities with marginal beveling showed less marginal staining than those placed in non-beveled cavities.
\end{abstract}

Key words: Clinical trial. Composite resins. Bevel. Dental restoration, permanent.

\section{INTRODUCTION}

Despite significant improvements in dental materials, especially regarding composite resin, some problems are still present, such as polymerization shrinkage and a long lasting sealing at the interface composite/dental structure, which could cause postoperative sensitivity, marginal staining and possible pulpal problems ${ }^{1,10}$. Several techniques have been developed to prevent or reduce these undesirable problems, like incremental technique to reduce the $\mathrm{C}$-factor ${ }^{4}$, improved adhesive systems ${ }^{23}$ and different cavities ${ }^{5,15,18}$. Bevel has been associated with beneficial results for composite restorations in anterior teeth: transversal exposition of the enamel prisms, favoring acid etching ${ }^{19}$, increase in the surface area to be conditioned, enhancing the adhesion ${ }^{6}$, reduction in microleakage ${ }^{15}$ and increase of the resistance to fracture of restored teeth ${ }^{5}$. Based on these improvements, bevel preparation in posterior composite restorations may be considered to improve the clinical performance of these restorations?.

Generally, clinical evaluation of restorations has been performed using the USPHS system (Ryge Criteria) 2,3,13,14,16,20,22,24. However, this method presents some shortcomings, especially in view of the new concepts regarding caries development. Recently, Hickel, et al. ${ }^{11}$ (2007), in a task force 
from the Fédération Dentaire Internationale (FDI), elaborated a new proposal to evaluate restorations that could provide better individualization of the data, improving standardization and making the data from different studies comparable. The aim of this randomized clinical trial was to evaluate posterior composite restorations prepared with or without bevel, using the FDI criteria, after 1-year follow-up.

\section{MATERIAL AND METHODS}

\section{Study design}

This study was a double-blind randomized clinical trial using the split mouth design. Class I or II were prepared in molars or premolars, with or without bevel preparation. The study had the approval of the local Research Ethics Committee (CEP-ULBRA 2007-170H).

Thirteen patients were selected and signed an informed consent form to participate in the study. The patients should be aged 20-30 years, males or females, each one needing at least two Class I or II, in the mandible or maxilla. Patients with poor oral hygiene, parafunctional habits, tooth requiring large restorations and teeth without antagonist were excluded from the study.

Each patient received two restorations, both performed with the composite resin Filtek P60 (3M/ESPE, St Paul, MN, USA) and the adhesive system Adper Single Bond (3M/ESPE, St Paul, MN, USA), which were used following manufacturers' instructions. The restorations were randomly assigned for two groups: Group 1: cavities without bevel (butt joint) $(n=14)$; Group 2: cavities with bevel $(n=15)$. The bevel was prepared in the enamel cavosurface angle using a diamond bur 2135 (KG Sorensen, Alphaville, SP, Brazil), with an inclination of $45^{\circ}$.

All restorations were placed using rubber dam to avoid contamination. The operative procedures were made under air-water spray cooling to avoid pulp damage. A metallic matrix with wooden wedge was used for class II preparations. A halogen light curing unit (XL 3000; 3M/ESPE), with an energy higher than $450 \mathrm{~mW} / \mathrm{cm}^{2}\left( \pm 50 \mathrm{mw} / \mathrm{cm}^{2}\right)$ was used throughout the experiment and the energy was constantly monitored.

After placement of the restorations, finishing and polishing were performed using diamond burs $\mathrm{n}^{\circ}$ $3195 \mathrm{~F}$ or $1190 \mathrm{~F}$ (KG Sorensen) and Enhance system (Dentsply, York, PA, USA). The operators were trained and calibrated to perform the restorations.

All restorations were evaluated soon after polishing (Baseline) by a calibrated examiner (Kappa intraexaminer), according to the FDI method 7,11 , which is composed by 5 scores for each one of the different criteria. Only restorations classified as clinically excellent for all criteria were included in the follow-up period.

After 6 months $^{7}$ and 1 year, restorations were re-evaluated by the same examiner from baseline, using the same evaluation method.

Data obtained after 1 year of evaluation were subjected to statistical analysis using the MannWhitney test, with the significant level of $p<0.05$.

\section{RESULTS}

Twenty-nine restorations were placed in 13 patients, being: 24 molars and 5 premolars; 14 without bevel (butt joint) and 15 with bevel; 17

Table 1- Six-months clinical evaluation of restorations: functional properties

\begin{tabular}{|c|c|c|c|c|c|c|}
\hline & $n$ & $\begin{array}{l}\text { Clinically } \\
\text { excellent }\end{array}$ & $\begin{array}{l}\text { Clinically } \\
\text { good }\end{array}$ & $\begin{array}{l}\text { Clinically } \\
\text { sufficient }\end{array}$ & $\begin{array}{c}\text { Clinically } \\
\text { unsatisfactory }\end{array}$ & Clinically poor \\
\hline \multicolumn{7}{|l|}{$\begin{array}{l}\text { Functional } \\
\text { Properties }\end{array}$} \\
\hline \multicolumn{7}{|l|}{$\begin{array}{l}\text { Fractures and } \\
\text { Retention }\end{array}$} \\
\hline 1- No bevel & 14 & 12 & 1 & 1 & - & - \\
\hline 2- Beveled & 15 & 12 & 3 & - & - & - \\
\hline Total & 29 & 24 & 4 & 1 & - & - \\
\hline Mann-Whitney & $P>0.05$ & Kappa= & 0.75 & & & \\
\hline \multicolumn{7}{|l|}{$\begin{array}{c}\text { Marginal } \\
\text { adaptation }\end{array}$} \\
\hline 1- No bevel & 14 & 14 & - & - & - & - \\
\hline 2- Beveled & 15 & 14 & 1 & - & - & - \\
\hline Total & 29 & 28 & 1 & - & - & - \\
\hline Mann Whitney & $P>0.05$ & Kappa= & 1 & & & \\
\hline
\end{tabular}


Table 2- One-year clinical evaluation of restorations: functional properties

\begin{tabular}{|c|c|c|c|c|c|c|}
\hline & $\mathrm{n}$ & $\begin{array}{l}\text { Clinically } \\
\text { excellent }\end{array}$ & $\begin{array}{l}\text { Clinically } \\
\text { good }\end{array}$ & $\begin{array}{l}\text { Clinically } \\
\text { sufficient }\end{array}$ & $\begin{array}{c}\text { Clinically } \\
\text { unsatisfactory }\end{array}$ & Clinically poor \\
\hline \multicolumn{7}{|l|}{$\begin{array}{l}\text { Functional } \\
\text { Properties }\end{array}$} \\
\hline \multicolumn{7}{|l|}{$\begin{array}{l}\text { Fractures and } \\
\text { Retention }\end{array}$} \\
\hline 1- No bevel & 14 & 12 & 2 & - & - & - \\
\hline 2- Beveled & 15 & 13 & 2 & - & - & - \\
\hline Total & 29 & 25 & 4 & - & - & - \\
\hline Mann-Whitney & $P=0.98$ & Kappa= & 0.75 & & & \\
\hline \multicolumn{7}{|l|}{$\begin{array}{c}\text { Marginal } \\
\text { adaptation }\end{array}$} \\
\hline 1- No bevel & 14 & 11 & 3 & - & - & - \\
\hline 2- Beveled & 15 & 13 & 2 & - & - & - \\
\hline Total & 29 & 24 & 5 & - & - & - \\
\hline Mann-Whitney & $P=0.72$ & Kappa= & 1.0 & & & \\
\hline
\end{tabular}

Table 3- Six-months clinical evaluation of restorations: biological properties

\begin{tabular}{|c|c|c|c|c|c|c|}
\hline & $\mathbf{n}$ & $\begin{array}{l}\text { Clinically } \\
\text { excellent }\end{array}$ & $\begin{array}{c}\text { Clinically } \\
\text { good }\end{array}$ & $\begin{array}{l}\text { Clinically } \\
\text { sufficient }\end{array}$ & $\begin{array}{c}\text { Clinically } \\
\text { unsatisfactory }\end{array}$ & Clinically poor \\
\hline \multicolumn{7}{|l|}{$\begin{array}{l}\text { Biological } \\
\text { Properties }\end{array}$} \\
\hline \multicolumn{7}{|c|}{$\begin{array}{l}\text { Postoperative } \\
\text { hypersensitivity }\end{array}$} \\
\hline 1- No bevel & 14 & 14 & - & - & - & - \\
\hline 2- Beveled & 15 & 15 & - & - & - & - \\
\hline Total & 29 & 29 & - & - & - & - \\
\hline \multicolumn{7}{|l|}{ Kappa=1.0 } \\
\hline \multicolumn{7}{|c|}{$\begin{array}{l}\text { Recurrence of } \\
\text { caries }\end{array}$} \\
\hline 1- No bevel & 14 & 14 & - & - & - & - \\
\hline 2- Beveled & 15 & 15 & - & - & - & - \\
\hline Total & 29 & 29 & - & - & - & - \\
\hline Kappa=1.0 & & & & & & \\
\hline
\end{tabular}

class I and 12 class II cavities. Data referring to the scores obtained for the different criteria at 6-month evaluation are presented in Tables 1, 3 and 5, and at 1-year are presented in Tables 2, 4 and 6.

Beveled and non-beveled cavities showed no statistically significant difference $(p>0.05)$ after 1 year follow-up, for most criteria: fractures and retention, marginal adaptation, postoperative hypersensitivity, recurrence of caries, surface luster and anatomic form. The only difference was observed for surface and marginal staining, as the beveled cavities showed significantly less marginal staining $(P=0.04)$ than non-beveled cavities.

\section{DISCUSSION}

The present study showed that posterior composite restorations performed well after 1 year and beveled cavities presented similar behavior than non beveled cavities, but with better marginal sealing, corroborating previous laboratory studies $^{15,18}$.

Longitudinal studies are considered outstanding studies to generate scientific based evidence regarding treatment procedures ${ }^{8,9}$.

Few clinical data are available in the literature concerning the effect of bevel preparation, 
Table 4- One-year clinical evaluation of restorations: biological properties

\begin{tabular}{|c|c|c|c|c|c|c|}
\hline & $\mathbf{n}$ & $\begin{array}{l}\text { Clinically } \\
\text { excellent }\end{array}$ & $\begin{array}{c}\text { Clinically } \\
\text { good }\end{array}$ & $\begin{array}{l}\text { Clinically } \\
\text { sufficient }\end{array}$ & $\begin{array}{c}\text { Clinically } \\
\text { unsatisfactory }\end{array}$ & Clinically poor \\
\hline \multicolumn{7}{|l|}{$\begin{array}{l}\text { Biological } \\
\text { Properties }\end{array}$} \\
\hline \multicolumn{7}{|l|}{$\begin{array}{l}\text { Postoperative } \\
\text { hypersensitivity }\end{array}$} \\
\hline 1- No bevel & 14 & 13 & 1 & - & - & - \\
\hline 2- Beveled & 15 & 15 & - & - & - & - \\
\hline Total & 29 & 28 & 1 & - & - & - \\
\hline Mann-Whitney & $P=0.75$ & Kappa= & 1 & & & \\
\hline \multicolumn{7}{|l|}{$\begin{array}{l}\text { Recurrence of } \\
\text { caries }\end{array}$} \\
\hline 1- No bevel & 14 & 14 & - & - & - & - \\
\hline 2- Beveled & 15 & 15 & - & - & - & - \\
\hline Total & 29 & 29 & - & - & - & - \\
\hline Карра=1.0 & & & & & & \\
\hline
\end{tabular}

Table 5- Six-months clinical evaluation of restorations: aesthetic properties

\begin{tabular}{|c|c|c|c|c|c|c|}
\hline & $\mathbf{n}$ & $\begin{array}{l}\text { Clinically } \\
\text { excellent }\end{array}$ & $\begin{array}{l}\text { Clinically } \\
\text { good }\end{array}$ & $\begin{array}{l}\text { Clinically } \\
\text { sufficient }\end{array}$ & $\begin{array}{c}\text { Clinically } \\
\text { unsatisfactory }\end{array}$ & Clinically poor \\
\hline \multicolumn{7}{|l|}{$\begin{array}{l}\text { Aesthetic } \\
\text { Properties }\end{array}$} \\
\hline \multicolumn{7}{|l|}{ Surface Luster } \\
\hline 1- No bevel & 14 & 8 & 5 & 1 & - & - \\
\hline 2- Beveled & 15 & 10 & 5 & - & - & - \\
\hline Total & 29 & 18 & 10 & 1 & - & - \\
\hline Mann-Whitney & $P>0.05$ & Kappa= & 0.75 & & & \\
\hline \multicolumn{7}{|l|}{$\begin{array}{l}\text { Surface and } \\
\text { marginal } \\
\text { staining }\end{array}$} \\
\hline 1- No bevel & 14 & 8 & 6 & - & - & - \\
\hline 2- Beveled & 15 & 14 & 1 & - & - & - \\
\hline Total & 29 & 22 & 7 & - & - & - \\
\hline Mann-Whitney & $p=0.025$ & Kappa= & 0.66 & & & \\
\hline \multicolumn{7}{|l|}{ Anatomic form } \\
\hline 1- No bevel & 14 & 12 & 1 & 1 & - & - \\
\hline 2- Beveled & 15 & 14 & 1 & - & - & - \\
\hline Total & 29 & 26 & 2 & 1 & - & - \\
\hline Mann-Whitney & $P>0.05$ & Kappa= & 1.0 & & & \\
\hline
\end{tabular}

especially in posterior teeth?. Bevel preparation has been reported to produce some beneficial effects in composite restorations: removal of the aprismatic layer of enamel, favoring the acid etching; increase of the surface energy and wettability of the substrate; increase of surface area for acid etching, reducing microleakage and improving marginal seal; improvement of esthetics, masking the interface between enamel and composite and, increasing the restoration retention $2,6,12,15,17,18$. The only disadvantage related to bevel preparation is the removal of additional sound tissue; however, this is a small removal of dental structure, which is overcome by the improved sealing obtained for 
Table 6- One-year clinical evaluation of restorations: aesthetic properties

\begin{tabular}{|c|c|c|c|c|c|c|}
\hline & $\mathbf{n}$ & $\begin{array}{l}\text { Clinically } \\
\text { excellent }\end{array}$ & $\begin{array}{l}\text { Clinically } \\
\text { good }\end{array}$ & $\begin{array}{l}\text { Clinically } \\
\text { sufficient }\end{array}$ & $\begin{array}{c}\text { Clinically } \\
\text { unsatisfactory }\end{array}$ & Clinically poor \\
\hline \multicolumn{7}{|l|}{$\begin{array}{l}\text { Aesthetic } \\
\text { Properties }\end{array}$} \\
\hline \multicolumn{7}{|l|}{ Surface Luster } \\
\hline 1- No bevel & 14 & 7 & 6 & 1 & - & - \\
\hline 2- Beveled & 15 & 9 & 6 & - & - & - \\
\hline Total & 29 & 16 & 12 & 1 & - & - \\
\hline Mann-Whitney & $P=0.56$ & Kappa= & 0.75 & & & \\
\hline \multicolumn{7}{|l|}{$\begin{array}{c}\text { Surface and } \\
\text { marginal } \\
\text { staining }\end{array}$} \\
\hline 1- No bevel & 14 & 6 & 8 & - & - & - \\
\hline 2- Beveled & 15 & 13 & 2 & - & - & - \\
\hline Total & 29 & 19 & 10 & - & - & - \\
\hline Mann-Whitney & $p=0.04$ & Kappa= & 0.66 & & & \\
\hline \multicolumn{7}{|l|}{ Anatomic form } \\
\hline 1- No bevel & 14 & 11 & 2 & 1 & - & - \\
\hline 2- Beveled & 15 & 14 & 1 & - & - & - \\
\hline Total & 29 & 25 & 3 & 1 & - & - \\
\hline Mann-Whitney & $P=0.49$ & Kappa= & 1.0 & & & \\
\hline
\end{tabular}

beveled cavities ${ }^{5}$.

In the present study, the method proposed by the FDI was used to evaluate the longevity of posterior restorations ${ }^{11}$. This method represented a significant improvement in the evaluation accuracy when compared to the widely employed USPHS method (United States Public Health Service - Ryge Criteria $)^{1-3,13,14,16,20,22,24}$. This new method presents a larger number of scores making it easier to establish potential differences regarding restoration quality. Moreover, this method allows the evaluation of the different categories: functional, biological and esthetic. The task force that developed this new method recommends its use in clinical studies to facilitate future comparisons between different investigations ${ }^{8,11}$.

Non-beveled and beveled cavities performed similarly in almost all the criteria evaluated in this study. Nevertheless, beveled cavities exhibited better marginal sealing and this finding could be related to the benefits provided by the bevel, as previously reported here. The more favorable exposure of enamel prisms after bevel preparation ${ }^{19}$ improves the marginal seal ${ }^{5,18}$, making difficult the penetration of substances or bacterial by products along of the interface ${ }^{15}$. Swanson, et al. ${ }^{21}$ (2008) observed less microleakage in beveled cavities compared to butt-joint restorations, when using etch-and-rinse adhesive system, like the one used in our study.
This study presents some limitations, such as the small number of patients and the relative short-term follow-up (1-year). However, even with these limitations, it was possible to detect differences between treatments. The authors are following the patients for longer periods of time in order to evaluate the longevity of the posterior composite restorations with or without bevel. Longterm clinical trials are the outstanding method to provide scientific evidence regarding the durability of restorative treatments.

\section{CONCLUSION}

Within the limitations of this study, it may be concluded that: 1 . After 1 year of follow-up, all restorations were acceptable, regardless of the type of cavity preparation; 2. Beveled and nonbeveled cavities performed similarly in most of the criteria evaluated; but beveled cavities showed less marginal staining.

\section{REFERENCES}

1- Barnes DM, Blank LW, Thompson VP, Houston AM, Gingell JC. A 5- and 8-year clinical evaluation of a posterior composite resin. Quintessence Int. 1991;22:143-51.

2- Brackett WW, Browning WD, Brackett MG, Callan RS, Blalock JS. Effect of restoration size on the clinical performance of posterior "packable" resin composite over 18 months. Oper Dent. 2007;32:212-6. 
3- Brunthaler A, König F, Lucas T, Sperr W, Schedle A. Longevity of direct resin composite restorations in posterior teeth. Clin Oral Invest. 2003;7:63-70.

4- Carvalho RM, Pereira JC, Yoshiyama M, Pashley DH. A review of polymerization contraction: the influence of stress development versus stress relief. Oper Dent. 1996;21:17-24.

5- Coelho-de-Souza FH, Camacho GB, Demarco FF, Powers J. Fracture resistance and gap formation of MOD restoration: influence of restorative technique, bevel preparation and water storage. Oper Dent. 2008;33:37-43.

6- Coelho-de-Souza FH, Camacho GB, Demarco FF, Powers $\mathrm{J}$. Influence of restorative technique, beveling and aging on composite bonding to sectioned incisal edges. J Adhes Dent. 2008;10:113-7.

7- Coelho-de-Souza FH, Klein-Júnior CA, Camargo JC, Beskow T, Balestrin MD, Demarco FF. Double-blind randomized clinical trial of posterior composite restorations with or without bevel: 6-month follow-up. J Contemp Dent Pract. 2010;11:1-8.

8- Da Rosa Rodolpho PA, Donassollo TA, Cenci MS, Loguércio AD, Moraes RR, Bronkhorst EM, et al. 22-Year clinical evaluation of the performance of two posterior composites with different filler characteristics. Dent Mater. 2011;27:955-63.

9- Demarco FF, Corrêa MB, Cenci MS, Moraes RR, Opdam NJ. Longevity of posterior composite restorations: not only a matter of materials. Dent Mater. 2012;28:87-101.

10- De Munck J, Van Landuyt K, Peumans M, Poitevin A, Lambrechts $P$, Braem $M$, et al. A critical review of the durability of adhesion to tooth tissue: methods and results. J Dent Res. 2005;84:118-32.

11- Hickel R, Roulet JF, Bayne S, Heintze SD, Mjor I, Peters M, et al. Recommendations for conducting controlled clinical studies of dental restorative materials. Science Committee Project 2/98. FDI World Dental Federation study design (Part I) and criteria for evaluation (Part II) of direct and indirect restorations including onlays and partial crowns. J Adhes Dent. 2007;9:121-47.

12- Hoelscher DC, Gregory WA, Linger JB, Pink FE. Effect of light source position and bevel placement on facial margin adaptation of resin-based composite restorations. Am J Dent. 2000;13:171-5. 13- Leirskar J, Henaug T, Thoresen NR, Nordbø H, von der Fehr FR. Clinical performance of indirect composite resin inlays/onlays in a dental school: observations up to 34 months. Acta Odontol Scand. 1999;57:216-20.
14- Moura FRR, Piva E, Lund RG, Palha B, Demarco FF. One-year clinical evaluation of two polyacid-modified resin composites (compomers) in posterior permanent teeth. J Adhes Dent. 2004;6:157-62.

15- Opdam NJM, Roeters JJM, Kuijs R, Burgersdijk RCW. Necessity of bevels for box only Class II composite restoration. J Prosthet Dent. 1998;80:274-9.

16- Pallesen U, Qvist V. Composite resin fillings and inlays. An 11-year evaluation. Clin Oral Investig. 2003;7:71-9.

17- Peixoto RT, Poletto LT, Lanza MD, Buono VT. The influence of occlusal finish line configuration on microleakage of indirect composite inlays. J Adhes Dent. 2002;4:145-50.

18- Schmidlin PR, Wolleb K, Imfeld T, Gygax M, Lussi A. Influence of beveling and ultrasound application on marginal adaptation of box-only Class II (slot) resin composite restorations. Oper Dent. 2007;32:291-7.

19- Sharpe AN. Influence of the crystal orientation in human enamel on its reactivity to acid as shown by high resolution microradiography. Arch Oral Biol. 1967;12:583-92.

20- Sturdevant JR, Lundeen TF, Sluder TB Jr, Leinfelder KF. Threeyear study of two light-cured posterior composite resins. Dent Mater. $1986 ; 2: 263-8$.

21- Swanson TK, Feigal RJ, Tantbirojn D, Hodges JS. Effect of adhesive systems and bevel on enamel margin integrity in primary and permanent teeth. Pediatr Dent. 2008;30:134-40.

22- Van Dijken JW. Direct resin composite inlays/onlays: an 11 year follow-up. J Dent. 2000;28:299-306.

23- Van Meerbeek B, De Munck J, Yoshida Y, Inoue S, Vargas M, Vijay $\mathrm{P}$, et al. Buonocore memorial lecture. Adhesion to enamel and dentin: current status and future challenges. Oper Dent. 2003;28:215-35.

24- Wassell RW, Walls AW, McCabe JF. Direct composite inlays versus conventional composite restorations: 5-year follow-up. J Dent. $2000 ; 28: 375-82$. 